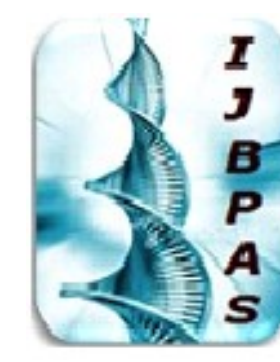

International Journal of Biology, Pharmaey and Allied Sciences (IJBPAS)

'A Bridge Betueen Caboratory and QRendo'

WwW.iibpas.com

\title{
BIOETHANOL PRODUCTION: WASTE MANAGEMENT
}

\section{DESAI N ${ }^{1}$, UPADHAYAY $\mathrm{D}^{2}$, MARCHAWALA $\mathrm{F}^{2}$, ANDHARE $\mathbf{P}^{2}$ AND BHATTACHARYA $\mathbf{I}^{2 *}$}

1: PG Scholar, Department of Biotechnology, Parul Institute of Applied Sciences, Parul University, Waghodia, Gujarat, India-391760

2: Assistant Professor, Department of Biotechnology and Microbiology, Parul Institute of Applied Sciences, Parul University, Waghodia, Gujarat, India-391760

*Corresponding Author: E Mail: Indrani Bhattacharya: E Mail: ibd9904035346@gamil.com; Tel: $\mathbf{+ 9 1 9 9 0 4 0 3 5 3 4 6}$

Received 21 ${ }^{\text {st }}$ Jan. 2021; Revised 23 ${ }^{\text {rd }}$ Feb. 2021; Accepted 24 ${ }^{\text {th }}$ March 2021; Available online $1^{\text {st }}$ April 2021

\section{https://doi.org/10.31032/IJBPAS/2021/10.4.1023}

\section{ABSTRACT}

Astounding supplies of petrol and growth of environment concern has been leading to the interest of increasing biomass as a feedstock for liquid fuel in developed and developing countries. Bioethanol presently used in vehicles either as fuel or mixed in form of gasoline. Liquid biofuel is the most widely used biofuel and which is produced as a result of this process of fermentation obtained from sugars cellulose or starches, biomass from decayed fruits. This study was designed to utilize the decayed fruits to produce biofuel and for the purpose of waste management. The main producers are countries like States and Brazil. The fermentation process starts with the production of ethanol from the decayed fruits which was compared regarding fermentation of fruits. Present study deals with bioethanol production from decayed fruits with isolation of bacteria with inoculation process from respective fruits, decayed fruits serve as a potential feedstock for bioethanol production due to more content of sugar and cost friendly substrate. The number of factors related to the fermentation affects the process and are optimized for efficient ethanol production.

Keywords: Biofuel, fermentation, bioethanol, fruit wates, incubation 


\section{INTRODUCTION}

Increasing prices of fuel for the past few year's concerns for environment because of climate change have lead to an increasing interest in biofuels. Biofuel are renewable and also substitutes fossil fuels which reduces greenhouse gas emission. Accordingly [1] reported that life cycle, economic, energy assessment provides policy for use of energy. They can be produced according to the need; biofuels are the first generation biofuels, mostly produced from maize, sugarcane and grapes. The inevitability of oil depletion, global warming and greenhouse effects put the earth on an alarming situation according to [2].

The ultimate source of energy is bioethanol when it comes to exception of fuels, bioenergy represents the utilization of biomass and have received special attention in global market [3] as starting material for the production of sustainable fuels either as a sole fuel in vehicle with engine blends which requires modification for engine when mixed upto $29.5 \%$ as additive fuels. Complex sugar that can later form soluble sugar in form of biomass is used to produce bioethanol. The feedstock is divided mostly into three major groups starch containing crops, (by product from sugar refineries and sugar crops). Lignocellulosic biomass (LCB) they differ respectively from the sugar solutions from the groups.
Lignocellulosic biomass (LCB), (sugarcane bagasse straws stalk) are used for the processes of second generation. More the amount of sugar utilized in any plant material more the source of raw materials helps in more production of bioethanol. Pineapple, grapes, banana and apple are the major plants that results in a good and more amount of yield for bioethanol production as a by product which is the result of high amount of sugar content present inside it. Due to dwindling supply of fuels the production of biofuels are considered as relevant technologies by both industrialized and developing countries are due to number of factors including environmental concerns like biofuels are non-toxic, biodegradable and free of carcinogenic content and sulphur. Biofuels are liquid or gaseous fuels made from plant matter and residue such as agricultural crops, municipal wastes and decayed fruits and agricultural waste and forestry by-products. The present study is conducted to determine the proper production of biofuel from different decayed fruits to bio-ethanol production, temperature and to identify the bacteria which helps in this fermentation system. This paper will deal with the investigative works on bioethanol production from sugar juices obtained from several energy crops along with fermentation technology, microorganisms 
used, and the influencing parameters on the process. Bioethanol from lignocellulosic biomass has recently been studied extensively but still it is confined to the laboratory or pilot plant. It is easier and cheaper to use free sugar containing juice as feedstock of ethanol than starch or lignocellulosic biomass due to the no requirement of costly steps such as pretreatment and/or hydrolysis to get fermentable sugars [4].

\section{FERMENTATION}

Batch, fed-batch, or continuous are the three methods of fermentation which is generally used for production of bioethanol [5]. The batch fermentation method is carried out, by adding feedstock to the fermentation tank with nutrients, microorganism, and other ingredients, fermentation of whole batch of ethanol, followed in fed-batch mode, one or many feedstocks are added to the vessel as fermentation is going on [6]. Constant input of ingredients and removal of output from the fermentation tank involves continuous fermentation [7]. Feedstock nature and kinetic of microorganisms decides which fermentation should be performed. Batch fermentation is the simple fermentation process due to low cost, less control requirement, easier sterilization, and management of feedstock as well as employment of unskilled workforce. Besides, most of the ethanol production study from juice feedstock was carried out by batch fermentation [8] d-batch mode is broadly employed in industrial production due to compiling the benefits from both batch and continuous processes [9]. Some advantages of the fermentation method over conventional batch process such as less inhibitory effect of higher substrate concentration, maintenance of maximum viable cell concentration, extended lifespan of cell, higher product accumulation, and control of other critical factors like $\mathrm{pH}$, temperature, and dissolved $\mathrm{O}_{2}$ at a specific level [10]. Continuous fermentation that can be carried out in mainly two basic types of reactors; for example, plug flow reactor and continuous stirred tank reactor offer some advantages over batch fermentation. This mode of fermentation needs less downtime for vessel cleaning and filling giving increased productivity with lower cost [11]. The hydrolysis process break downs the cellulosic part of fruit waste or biomass into sugar solutions that can be that can be fermented into ethanol. Then heating takes place after the addition of yeast like S.Cerevisiae. The yeast consists of enzyme called invertase which act as a catalyst which converts sucrose sugars into glucose and fructose $\left(\mathrm{C}_{6} \mathrm{H}_{12} \mathrm{O}_{6}\right)$. Then another enzyme called zymase reacts with the fructose and glucose sugars which is itself present inside the yeast to produce 
carbon dioxide and ethanol. Temperature is generally maintained between $25^{\circ} \mathrm{C}-30^{\circ} \mathrm{C}$.

\section{BIOETHANOL}

In 1980s, Rudolf Diesel was a first person who made biodiesel from vegetable oil. In 1970s and 1980s environmental protection agency EPA situated in America suggested that the fuel should be free from sulphur dioxide, carbon monoxide, and carbon monoxide source and nitrogen oxides. In 1998 the EPA allowed the production of biofuel on commercial level which was the alternative source of petrol. In 2010 the production of biofuel reaches up to 105 billion litres worldwide. In 2011, European countries were the largest that made biodiesel almost about 53\%. The international Energy Agency set a goal to reduce the usage of petroleum and coal and will be switched on to biofuels till 2050 . The petrol substitute for any kind of vehicular use has a principle fuel like bioethanol. It mainly has a production from a sugar fermentation, although there are also some chemical processes like ethylene reaction with steam can also be done. The main source of producing fuel generally comes from energy crops and by energy crops different researchers mean fruits or vegetable waste. There is also on-going research carried upon the municipal waste to produce ethanol or biofuel. By the mean of bioethanol production ethanol $\left(\mathrm{C}_{2} \mathrm{H}_{5} \mathrm{OH}\right)$ production is very important as it's a colourless liquid, it is biodegradable low in toxicity. Ethanol is a burning element to produce carbon dioxide and water. Ethane is high octane fuel and hence it has lead by the octane enhancer in petrol. By the blend mixture of gasoline and ethanol the fuel mixture can also be oxygenated so it burn more and reduce polluting elements. The fuel is largely sold in United States which is one of the reason we should increase the production of biofuel in India and enter as a developed country like United States. The mostly commonly used mixture is $90 \%$ fuel and $10 \%$ ethanol. Only flexible fuel suited vehicles can run it engine upto $15 \%$ fuel and $85 \%$ ethanol $[\mathbf{1 2}, \mathbf{1 4}]$.

\section{ADVANTAGES AND PURPOSE}

Bioethanol is the most useful biofuel which is an alternative source of fossil fuel has received special attention in global market. This study will give more knowledge on a potential of biofuel that can be produced for the scientific community and public for further studies regarding bioethanol production from waste. The objectives regarding bioethanol production waste. The objectives of the research are to determine the bioethanol percentage from fruit waste through a fermentation process using yeast, Sacchromyces cerevisiae and to analyse the chemical amount and glucose content in production of bioethanol using various fruits waste. The advantage of biofuel includes lower emission green gas, 
renewable, biodegradable and safer and long lasting. Utilization of spent residues can also be done by feedstock for biogas digester to obtain biogas and measure. Can also be used as animal fodder after removing toxic chemical elements. These may be composted or maybe utilized for traditional uses of food waste [14].

\section{MICROORGANISMS}

Involvement of microorganisms in fermentation of sugars is a crucial part of bioethanol production. Some microorganisms have the ability to use glucose in the absence of oxygen for their energy, producing ethanol and carbon dioxide [12-14]. This property makes them potential bio agents in fermentation technology from the beginning of its history. Sugar fermentation using single cell microorganism, that is, yeast, is one of the oldest practices in biotechnology, widely used for the production of drinking alcohol, namely, beer and wine, in the past time, while, nowadays, this practice is industrially used to produce fuel ethanol from renewable energy sources [15-16]. Major characteristics of ethanol genic microorganisms to be employed in industrial plants are higher ethanol yield $(>90.0 \%$ theoretical yield), tolerance to ethanol $(>40.0 \mathrm{~g} / \mathrm{L}), \quad$ good ethanol productivity $(>1.0 \mathrm{~g} / \mathrm{L} / \mathrm{h})$, good growth in simple and inexpensive media, capability of growth in undiluted fermentation broth with resistance to inhibitors, and ability to retard contaminants from growth condition, for example, acidic $\mathrm{pH}$ or higher temperature [16-17]. Yeast is described as basidiomycetous or ascomycetous fungi responsible for reproducing through fission or budding and formed spores which are not enclosed in the fruiting body [18]. S. cerevisiae is the most popular yeast in the production of ethanol due to its wide tolerance of $\mathrm{pH}$ makes it less susceptible to infection. Yeast has an ability to catabolize ix carbon molecules to the bioethanol production which are dependent on enzymes like alcohol dehydrogenase which is encoded on the ADH1 locus. During the fermentation of glucose, ADH1 catalyses led to the production of ethanol and reduction of acetaldehyde, similarly, the reverse reaction can be catalysed: is the process of conversion of ethanol to acetaldehyde, albeit with lower catalytic efficiency [19].

\section{Fossil fuels substitution:}

Due to excessive exploitation of fossil fuels, this world genuinely requires replacement for fuel in the future which can only be satisfied with biofuel. That could diminish the combined ill-effects of air, soil and water pollution and global warming [21].

Conversion of wastes in a productive way: 
This process would be beneficial for stakeholders like industrialists and famers. Lands with no cultivation could possibly be cultivated with suitable energy crops with non-feedstock [21].

Enhance the conventional fossil fuel composition with bioethanol additives:

Bioethanol performs as octane enhancer in unleaded gasoline in place of the methyltertiary butyl ether (MTBE). Combustion cleaning of the gasoline and improving the air quality is also done by bioethanol because it's an oxygenated compound [21].

\section{Use as an alternative fuel:}

The use of bioethanol as an alternative fuel reduce $\mathrm{CO}$ 2emissions, to partly substitute oil the limit risk of climate change and use a renewable energy sources is done [22].

\section{More number of added by-products gives more yeild:}

By a flourishing biomass market these bioethanol fuel production costs can be offset for use. The economic viability of working lands supports a positive incentive to help in preserving forests and farms and plants from the threat that keeps accelerating of the urban and semi urban areas and space [22].

\section{CONCLUSION}

Global warming is a universal issue for decreasing the purity of air and increasing pollution due to burning of fossil and thus alternative source of energy is a necessity. Carbohydrate fruit wastes and vegetable wastes can be used as essential stuff with consistent amount of elements for preparation of bioethanol. Bioethanol is source of energy in form of fuel generated from biodegradable fruit waste which also helps to reduce pollution. Use of biodegradable fuel use lead to decrease major energy issues Energy crisis the use of decayed fruits for bioethanol are cost effective and do not yield any toxic residues however optimization of substrate concentration and many environmental situations are required for an industrial application and other applications. Although current industrial fermentation for fuel ethanol production employs two types of feedstock such as free fermentable sugars and starch, free sugars containing juice is more economic than feedstock of starch instead directly it can be used in fermentation without any former treatment. However, better yield also depends on the selection of fermentation method, microorganisms and several other factors like technique. Also, development of different potential genetic types of juice producing waste will also enhance the commercial ethanol production. Several technological advances have already been searched, but haven't brought to use. Therefore, in a stable way a detailed 
economic process is required to develop a suitable production strategy industrially that will solve our energy crisis by producing more biofuel.

\section{REFERENCES}

[1] Hossain A. B. M. S. and A. R. Fazliny. Creation of alternative energy by bio-ethanol production from pineapple waste and the usage of its properties for engine. African Journal of Microbiology Research. 4 (6):2010, 813-819

[2] K Rajandran. Bioethanol from cassava by fermentation process from cassava by fermentation process using S.Cerevisiae. Faculty of Chemical and Natural Resources Engineering. University Pahang., 2013, p.2.

[3] Saifuddin M, GohP, HoE, et al. Biodiesel production from fruit waste cooking palm oil and environmental impact analysis. Bulgarian Journal of Agricultural Science, 20(1), 2014, 186-192

[4] Singh A, Kuila A, Adak. Utilization of vehetable wastes for bioenergy generation. Agricultural Research. 2012, p.3.

[5] S. Ganesh, A. F. Khan, M. Suresh, et al. "Character association for alcohol yield in sweet sorghum," Madras Agricultural
Journal, vol. 82, no. 5, 1995, pp. 361-363.

[6] M. Vitolo, "Production of ethanol and invertase by $S$. cerevisiae grown in blackstrap molasses," in Proceedings of the $7^{\text {th }}$ Biomass for Energy and the Environment, Pergamon Press, Copenhagen, Denmark. 1996 pp. 1477-1481,

[7] C. E. Wyman, "Ethanol fuels," in Encyclopedia of Energy, Elsevier, New York, NY, USA, pp. 541-555, 2004.

[8] J. M. Bvochora, J. S. Read, and R. Zvauya, "Application of very high gravity technology to the cofermentation of sweet stem sorghum juice and sorghum grain," Industrial Crops and Products, vol. 11, no. 1, 2000, pp. $11-17$.

[9] U. Saarela, K. Leiviskä, and E. Juuso, "Modelling of a fed-batch fermentation process," Report A 21, Control Engineering Laboratory, Department of Process and Environmental Engineering, University of Oulu, Oulu, Finland, 2003.

[10] A. Frison, K. Memmert, and A. N. Pharma, "Fed-batch process development for monoclonal antibody production with cellfermpro," Genetic Engineering \& 
Biotechnology News, vol. 22, 2002. pp. 66-67,

[11] J. C. Gunther, D. E. Seborg, and J. Baclaski, "Fault detection and diagnosis in industrial fed-batch fermentation," in Proceedings of the American Control Conference, pp. 5511-5516, June 2006.

[12] P. F. Stanbury, A. Whitaker, and S. J.Hall, Principles of Fermentation Technology, Pergamon Press, Oxford, UK, $2^{\text {nd }}$ edition, 1995, p-5

[13] F. S. Wang and C. H. Shyu, "Optimal feed policy for fed-batch fermentation of ethanol production by Zymomous

mobilis," Bioprocess Engineering, vol. 17 , no. 2 , 1997, pp. 63-68,

[14] S. Brethauer and C. E. Wyman, "Review: continuous hydrolysis and fermentation for cellulosic ethanol production," Bioresource Technology, vol. 101, no. 13, 2010, pp. 4862-4874.

[15] O. Deesuth, P. Laopaiboon, P. Jaisil, et al. "Optimization of nitrogen and metal ions supplementation for very high gravity bioethanol fermentation from sweet sorghum juice using an orthogonal array design," Energies, vol. 5, no. 9, 2012, pp. 3178-3197.

[16] L. Ingram, P. Gomez, X. Lai et al., "Metabolic engineering of bacteria for ethanol production,

"Biotechnology and Bioengineering, vol. 58 , no. $2-3,1998$, pp. 204 214.

[17] N. Kosaric and J. Velikonja, "Liquid and gaseous fuels from biotechnology: challenge and opportunities," FEMS Microbiology Reviews, vol. 16, no. 2-3, 1995, pp. 111-142.

[18] B. S. Dien, M. A. Cotta, and T. W. Jeffries, "Bacteria engineered for fuel ethanol production: current status," Applied Microbiology and Biotechnology, vol. 63, no. 3, 2003, pp. 258-266.

[19] Boekhout T, Krtzman CP. Principles and methods used in yeast classification and an overview of currently accepted yeast genera. In: Wolf K., editor. Nonconventional Yeasts in Biotechnology. Springer-Verlag; Berlin: (1996); 1-99.

[20] Mohd Azhar SH, Abdulla R, Jambo SA, et al. Yeasts in sustainable bioethanol production: A review. Biochemistry and Biophysics Reports, 10, 2017; 5261.

[21] Gnansounou, E., Dauriat, A., Ethanol Fuel from Biomass: A Review. Journal of Scientific and 
Industrial Research, Volume 64, 2005 , pp. 809-821.

[22] Hossain, N., Jalil, R. Sugar and Bioethanol Production from Oil
Palm Trunk (OPT). Asia Pacific Journal of Energy and Environment (APJEE), Volume 2(2), 2015, pp. 89-92. 